\title{
SPECIAL SERVICE MANAGEMENT OF SCHOOL LIBRARY
}

\author{
Wildan Zulkarnain \\ Department of Educational Management, State University of Malang, Indonesia \\ wildan.zulkarnain.fip@um.ac.id
}

\begin{abstract}
The focus of the research is to describe the specific service management processes in the school library SMPN 2 Malang. The research approach is qualitative with case study type. Data collection using interview techniques, observation, and documentation. Researchers serve as a key instrument that acts as a data collector, data analyzer, and report maker of research results. The findings of the study are the management of special services of school libraries in SMPN 2 Malang has fulfilled all management processes consisting of planning, organizing, implementation, and supervision. The four processes take place in a repetitive cycle, i.e. after the final process (supervision) has been passed, it will return again to the first process (planning). School library facilities and infrastructure are still inadequate. As well as reading interest of students is also still low.
\end{abstract}

Keywords: school libraries, specialized services

\section{INTRODUCTION}

Student-specific services include an important part of School-Based Management that is organized to optimize the achievement of school goals. The scope of special services in schools according to Mustiningsih (2011) includes services: counseling guidance, libraries, healthcare, laboratories, dormitories, transportation, cooperatives, stalls, intra-school student organizations, and inclusive education services. Based on this opinion then the school library is One form of special services in schools to create a reading culture of learners. Further Zulkarnain (2016) states that the school library as a source of learning will have a good performance if managed properly. With good management, then the library will be able to function optimally according to expected goals. So the management or management of the school library means all efforts to coordinate all activities related to the implementation of school libraries.

The term library comes from the basic word "library" which means holy book or book. Basuki (2010) explained that the library is derived from the Latin liber or libri which also means books. So it is not surprising to hear the term library, then people will imagine a building or room filled with bookshelves. But not just any collection of books can be called a library, and not just any collection of books can be called a library. But the collection of books and other library materials that must be arranged and arranged based on the provisions that have a specific purpose, so that can be called as a library.

Law Number 43 of 2007 defines the school / madrasah library as a library that is an integral part of the learning activities and serves as a learning resource center to support the achievement of educational goals that are located in the school. Specifically Prastowo (2012) states the school library as a means of supporting education in schools in the form of a collection of book or non-book library materials organized systematically in one room in order to help the students and teachers in the learning process.

The school library is very important to support the learning process in school. Learners are expected to solve a problem by going to the library to read and compare the theories studied. Or as a source of study for the usefulness of research and reference. Learners can also follow the development of existing knowledge so that they better understand the knowledge that has been given by their teachers. The library can also be used as a recreational tool to bring the interest of learners to visit the library by providing non-material library materials such as magazines, story books and novels. And design the space and the contents of the library interesting and comfortable to be visited by the wearer. The essential function of the school library as a learning resource center causes each school to provide an adequate source of learning resources through the school library. This library should enable educators, educators, and learners to have the opportunity to expand and deepen their knowledge by reading the literature that contains the knowledge needed in the teaching and learning process at school.

The focus of this research is to describe a special service management process School library at SMPN 2 Malang. School library in SMPN 2 Malang has existed since the establishment of SMPN 2 Malang. At the beginning of this library, the library materials are very limited and very less to meet the needs of learners in finding the information needed for the needs of learning. But with the passage of time, SMPN 2 Malang trying to improve the existing library materials by always adding more libraries so that the library collection more and more. Finally until now there are about 3000 library materials that exist in the library SMPN 2 Malang.

\section{METHODS}

This study uses a qualitative approach with case study types to reveal in detail the focus or problem under study. Researchers serve as a key instrument that acts as a data collector, data analyzer, and report maker of research results. The research location is SMPN 2 Malang is located at Jalan Prof. Moh Yamin 60 Malang City. The vision of this school is to become a superior school in quality that is based on the culture of the nation. School motto is "Satata Wiyata Mandalaning Bangsa" which means that SMP 2 is to educate and scored the younger generation to become future leaders.

Data collection uses in-depth interview techniques, observation, and documentation. Data sources are obtained from: words through interviews; 
Action from something observed by the researcher; And documentation in the form of photographs or other supporting documents. Key research informant is school library coordinator. Other informants were principals, librarian teachers, and students, who were used to cross check data with information from key informants.

The process of data analysis through the data reduction phase, the presentation of data in the form of narrative text, data verification, and withdrawal of conclusions. As Ulfatin (2013) opinion then checks the validity of the data is done by testing the trust (credibility), transferability, dependence (dependability) and certainty (confirmity). While the process of collecting research data through the preparation stage, stage of implementation, and stage reporting.

\section{RESULTS}

The process of library management in SMPN 2 Malang begins with the planning stage, i.e. the principal appoints one of the teachers whose less teaching hours as the school library coordinator. Teachers who are appointed as school library coordinators form the structure of the library management for one year period. The teacher of the library coordinator then appoints several teachers as the person in charge of each class, who are responsible for classes 7, 8, and 9 to help coordinate the management of school libraries.

After that start compiling and mapping the condition of library materials that are still appropriate or not in the school library and do the coding manually on existing library materials. The next activity is to determine the officers who guard in the school library, and determine the school operating hours of the school. Library managers are formed based on a letter of assignment issued by the principal who appoints one teacher as the library coordinator. The library coordinator is the general manager of school library management including having full authority in the school library and the implementation of the school library in accordance with the specified operating hours. The performance of the library coordinator is overseen by the school's facilities and infrastructure where the library coordinator should make a report at the end of each school year that will be given to the principal.

The library coordinator oversees the responsibility of the class in charge of assisting the library coordinator in directing and supervising the students in using the library material facilities in the school library. The library coordinator will also be assisted by two administrative staff appointed by the principal to assist in the technical management of the school library. SMPN 2 Malang library activity starts from 06.30 WIB until the return of students. This is done to provide library service facilities to learners who need reference materials for learning materials or as a task of doing tasks. Activity starts from the morning so that if learners need library materials before the learning time begins, then it can be available. Every day there will be two officers who guard to serve the borrowing and return of library materials. In addition there is also a manual coding activity for books that have not been encoded and arrangement on the bookshelf.

Preparation of books in the library using the Dewey decimal classification system or the Dewey Decimal Classification (DDC). The composition of the subjects in the DDC system covers the whole of human knowledge that can be divided into ten main classes (main classes) or can be referred by the First Summary (first summary). Each main class of the ten main classes are divided into ten sections or divisions called Second Summary (second summary). Then each division is further divided into ten sections called Third Summary (third summary). So the total number to a thousand sections and notation written consists of three numbers that should not be less. Primary class number in first position, division number in second position, and section number in third position.

On every effective day, school library activity begins with cleaning up the environment around the school library. Room cleanliness reading library and arrangement of seating reading also arranged before library opening hours. In addition, the arrangement of newspapers sent to the school library is also done every day. Supervision of school library management directly entrusted the principal to the teacher who is appointed as the school library coordinator who is directly supervised by the school facilities and infrastructure. The form of supervision is the library coordinator making reports on the management of school libraries in each academic year ending about daily visitor data, the amount of library material available in the school library, the attendance of the school library staff, the incoming books, the outgoing books, and school library financial reports including Late return of book penalty.

Every beginning of the school year will be assessed by the principal about the management of the school library during the previous year. It is considered that the school library management report and reports on library materials in the school library have been managed effectively or not. The principal with the school library coordinator and the person in charge of each class formed an evaluation meeting aimed at receiving reports and inputs related to school library management. Evaluation results will be followed up as improvements to school library management. Includes optimization of supporting resources for school library management such as: book donations from students who will graduate, self-help librarians, central government assistance through BOS, local government support through library grants, and library allocations derived from school funds. In addition, the addition of facilities that felt less like the addition of a desk chair and bookshelf.

\section{DISCUSSION}

The process of special service management of school libraries in SMPN 2 Malang begins with planning, then forwarded organizing, implementation, and finally supervision. This is in line with the opinion of Zulkarnain (2016) which states that the special 
service management process includes: (1) Planning, in the form of needs analysis and preparation of special service programs; (2) Organizing, in the form of division of tasks to carry out special service programs; (3) Movement, in the form of special service implementation arrangements; And (4) Supervision, in the form of monitoring and performance appraisal of special service programs in schools.

Sumiati (2011) mentions three steps that are included in the process of organizing the school library. First, the details of all the work that must be done to achieve the goal of establishing the school library. Second, the division of work in the school library work unit into activities that logically can be implemented by one person, that is not too heavy so it can not be solved or otherwise too light so there is idle time. Third, the procurement and development of a mechanism to coordinate the work of staff or school library personnel into a unified and harmonious unity.

Officers or librarians also have to master the technology, in addition to mastering library management, in the era of digital libraries today. This is according to Trisna \& Sobri (2014) required because librarians will face greater challenges in obtaining, storing, or retrieving information in the form of electronics. The existence of the development and advancement of information and communication technology requires school library personnel to understand and utilize positively and creatively in managing library materials.

School library facilities and infrastructure are still inadequate. Whereas according to Barnawi \& Arifin (2012) the library room consists of books, furniture, educational media, and other equipment. The books in the school include: textbooks, educator manuals, enriching books, reference books and learning resources. Library furnishings include: bookcases, magazine racks, newspaper racks, desks and reading chairs, library work desks and chairs, catalog cabinets, regular cabinets, bulletin boards and multimedia tables. Minimum library multimedia equipment 1 set of computer, TV, radio and DVD player. Other equipment needed in the library room are inventory books, bins, sockets, and wall clocks.

With respect to supervision, annual evaluation should cover all areas of activity contained in the planning documents. The fields according to Handoyo (2011) include items: whether service performance achieves the objectives and meets the objectives specified by libraries, curricula and schools; Whether service performance meets the needs of the school community; Whether performance is capable of meeting changing needs; Whether performance service resources are adequate; And whether the costeffectiveness of performance services.

Based on the results of a special service management research in the school library SMPN 2 Malang, it can do a SWOT analysis (Strength, Weakness, Opportunity, Threat) Which is inseparable from the strategic formulation as contained in Table 1. Rangkuti (2013) states that strategic formulations are compiled using SWOT analysis results by incorporating various indicators contained in strengths, weaknesses, opportunities, and threats. The merging model uses a matrix that includes: (1) SO strategies that are structured by using all forces to seize opportunities, (2) WO strategies that are structured by minimizing weaknesses to exploit existing opportunities; (3) ST strategy prepared by using all the power to deal with threats; And (4) WT strategies prepared by minimizing weaknesses to avoid threats.

Table 1

SWOT Analysis

\begin{tabular}{|c|c|c|}
\hline Eksternal & $\begin{array}{l}\text { Strength } \\
\text { - Coaching, training, and education of human } \\
\text { resources. } \\
\text { - The collection of encyclopaedias and fiction } \\
\text { books is quite complete } \\
\text { - Provision of library materials from } \\
\text { stakeholders. }\end{array}$ & $\begin{array}{l}\text { Weakness } \\
\text { - Lack of specialized librarians are not teachers. } \\
\text { - The library room is still too small. } \\
\text { - Support services are inadequate. }\end{array}$ \\
\hline $\begin{array}{l}\text { Opportunity } \\
\text { - Government policy in UU } 43 \text { of } \\
2007 \text {. } \\
\text { - The development of information } \\
\text { technology to improve the quality of } \\
\text { library services }\end{array}$ & $\begin{array}{l}\text { S-O Analysis } \\
\text { - Continuous collection of books can improve } \\
\text { the collection quality. } \\
\text { - Development of human resources to improve } \\
\text { the excellent service of librarians. } \\
\text { - The availability of library materials from } \\
\text { stakeholders can enhance the collection of } \\
\text { books. }\end{array}$ & $\begin{array}{l}\text { W-O Analysis } \\
\text { - UU } 43 \text { of } 2007 \text { embodies government } \\
\text { guarantees against: library development, } \\
\text { careers and welfare of librarians, and the } \\
\text { provision of collections and services. } \\
\text { - Use of information technology to improve the } \\
\text { quality of library services. }\end{array}$ \\
\hline $\begin{array}{l}\text { Threat } \\
\text { - Bad library image. } \\
\text { - Low user awareness. } \\
\text { - Student reading interest is still low. } \\
\text { - Security for less users. }\end{array}$ & $\begin{array}{l}\text { S-T Analysis } \\
\text { - The addition of library collection to improve } \\
\text { library image for the better. } \\
\text { - Fiction books and encyclopedias to enhance } \\
\text { and interest readers learn. }\end{array}$ & $\begin{array}{l}\text { W-T Analysis } \\
\text { - Add librarians who are not teachers. } \\
\text { - Adding facilities supporting school library } \\
\text { services that can attract visitors and ensure } \\
\text { their safety. }\end{array}$ \\
\hline
\end{tabular}

The SWOT analysis enables schools to identify the factors that affect both positive and negative inside and outside the organization. Suryatama (2014) stated SWOT analysis can be applied in various fields such as health, development, and or education. SWOT analysis can also help develop a full awareness of all the factors that can affect strategic planning and decision making. The main problem lies in the still low interest in reading learners, whereas the school library is a strategic place that is expected as a center of 
development activities of reading interest and reading habits. The school library has the duty and responsibility in fostering and developing the reading interest of school personnel. So it takes a good cooperation between librarians and teachers to foster awareness and reading habits and increase reading interest. Especially if the learners are still not widely required to read many other reading material outside the educational curriculum.

\section{CONCLUSIONS AND RECOMMENDATIONS}

\section{Conclusion}

The management of school library special services in SMPN 2 Malang has fulfilled all management processes consisting of planning, organizing, implementing and supervising. The four processes take place in a repetitive cycle, i.e. after the final process (supervision) has been passed, it will return again to the first process (planning). This means that the evaluation results from the supervision will be followed up as an improvement for the school library management. The library's special service activities are under the responsibility of the school library coordinator, a teacher assigned directly by the principal. School library facilities and infrastructure are still inadequate. As well as reading interest of students is also still low.

\section{Suggestion}

Based on the conclusions can be given advice to some parties. The principal should budget the operational funds for the school library on a regular basis so that the library supporting facilities are adequate. The school library coordinator is recommended to create a library service program that can attract visitors and can increase reading interest of learners. As for learners and teachers should be more active use of school libraries as a means to find information supporting teaching and learning activities.

\section{REFERENCES}

[1] Barnawi., \& Arifin, M. 2012. Manajemen Sarana \& Prasarana Sekolah. Jogjakarta: Ar-Ruzz Media.

[2] Basuki, S. 2010. Pengantar Ilmu Perpustakaan. Jakarta: Universitas Terbuka.

[3] Handoyo, S. 2011. Pemantauan dan Evaluasi Perpustakaan. (Online), (http://Sujarwo handoyo//perpustakaan-1991.blogspot.com/2011/11/ pemantauan-dan-evaluasi-perpustakaan.html), diakses 9 September 2014.

[4] Mustiningsih. 2011. Manajemen Layanan Khusus. Jurnal Manajemen Pendidikan, 23 (4): 347-356.

[5] Prastowo. 2012. Manajemen Perpustakaan Sekolah Profesional. Jogjakarta: Diva Press.

[6] Rangkuti F. 2013. SWOT Balanced Scorecard (Teknik Menyusun Strategi Komporat yang Efektif Plus Cara Mengelola Kinerja dan Risiko). Jakarta: PT Gramedia Pusaka Utama.

[7] Sumiati, O. 2011. Pengelolaan Perpustakaan Sekolah. Jakarta: Universitas Terbuka.

[8] Suryatama E. 2014. Lebih Memahami Analisis SWOT dalam Bisnis. Surabaya: Kata Pena.

[9] Trisna \& Sobri. 2014. Penyelenggaraan Digital Library dalam Meningkatkan Layanan Perpustakaan Bagi Para
Pemustaka. Jurnal Manajemen Pendidikan, 24 (4): 336-340.

[10] Ulfatin. 2013. Metode Penelitian Kualitatif di Bidang Pendidikan: Teori dan Aplikasinya. Malang: Bayumedia.

[11] Undang-Undang RI Nomor 43 Tahun 2007 tentang Perpustakaan.

[12] Zulkarnain, W. 2016. Layanan Khusus Peserta Didik Sebagai Penguat Manajemen Pendidikan. Prosiding Seminar Nasional, Penguatan Manajemen Pendidikan di Era Kompetisi Global. 1 (1): 52-65. 